\title{
Research on accounting information sharing mechanism from the perspective of national governance
}

\author{
Qu Jilin ${ }^{1, \mathrm{a}}$, Zhu Yicai ${ }^{1, \mathrm{~b}, *}$ \\ ${ }^{1}$ Shandong University of Finance and Economics Jinan, Shandong, China
}

\begin{abstract}
Accounting information sharing plays an important role in giving full play to the resource allocation effect of accounting information and promoting the modernization of national governance. It is one of the main tasks of the 13th five year plan for accounting reform and development of the Ministry of finance to establish a public service platform for social accounting information based on the disclosure of financial report data. In view of a series of problems brought about by the current accounting information multi submission, different caliber, mutual independence and non sharing, this paper discusses the mechanism and implementation path of accounting information sharing from the perspective of national governance, and puts forward a vertical through, horizontal interaction, internal integration and national unified accounting information sharing service system. Through the establishment of accounting information platform, accounting information can be "Count one, share resources".
\end{abstract}

\section{Introduction}

The Third Plenary Session of the 18th CPC Central Committee proposed that the overall goal of comprehensively deepening reform is to improve and develop the socialist system with Chinese characteristics, and promote the modernization of national governance system and governance capacity. The reform of economic system is the key point of deepening the reform in an all-round way. The core problem is to deal with the relationship between the government and the market, so that the market can play a decisive role in the allocation of resources and the government can play a better role.

Accounting information is important basic information reflecting economic activities. As the guide of resource allocation, the vane of capital market and the main carrier of economic information, accounting information plays an important role in national governance. However, for a long time, there are many problems in accounting information disclosure and sharing. On the one hand, the public disclosure of accounting information is incomplete, not timely, poor relevance, and the requirements of information users can not be met; on the other hand, the government departments can not share accounting information, do things in their own way, have different caliber, and submit multiple reports, resulting in the supervision departments can not organically combine, and it is difficult to ensure the pertinence, coordination and effectiveness of macro-control.
In order to change the situation that accounting information can not be shared, we have been exploring the way of accounting information sharing since the 1980s. The Ministry of finance has always regarded accounting information sharing as the main goal and general task of accounting reform and development, and put forward the goal of "counting one, sharing resources". In 2016, the Ministry of Finance issued the 13th five year plan for accounting reform and development, proposing to establish a public service platform for social accounting information based on the disclosure of financial report data ${ }^{[1]}$.

However, after nearly 40 years of exploration, accounting information sharing is still in its infancy. This paper studies it.

\section{National governance and accounting information sharing}

\section{1 accounting information sharing is the internal requirement of national governance}

The realization of accounting information "counting out one subject and sharing resources" is conducive to the role of accounting information in national governance, and is of great significance to promoting national governance. First, give full play to the guiding role of accounting information in resource allocation to promote the coordinated development of market economy; second, realize the interconnection and information sharing of government departments; on the one hand, promote the organic combination of various kinds of supervision to effectively curb the distortion of accounting information;

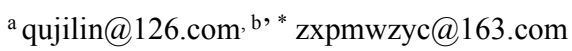


on the other hand, improve the coordination mechanism of regulation and control to form a joint force of regulation and control to enhance the foresight, pertinence and synergy of macro-control; and third, promote the development of macro-control. The public and other accounting information users provide simple and easy-to-use accounting information to meet the public's demand for accounting information.

\subsection{An analysis of the influence mechanism of accounting information on national governance}

First, accounting information promotes national governance through resource allocation. Accounting information is the information basis of resource allocation, and the market and government need accounting information in resource allocation; resource allocation is the basis of national governance, and the state adjusts dynamically according to resource allocation $^{[2]}$.

Second, there is synergy between national governance and accounting information. National governance has collaborative demand for accounting information. In order to meet the overall needs of national governance, the coordination of national governance and accounting information in different fields is needed. Accounting information is of great significance to economy, politics, culture, society, ecology and modernization of national governance. There is synergy among the internal accounting subsystems. Different accounting subsystems need coordinated development, and different accounting branches at different levels in different fields need coordinated development, so as to better serve national governance.

Third, the path of accounting information sharing serves national governance. Accounting information sharing provides sufficient and timely accounting information for national governance; accounting information sharing improves the quality of accounting information disclosure, so as to improve national governance; accounting information sharing reduces the cost of accounting information for national governance.

\section{The realization mechanism of accounting information sharing}

\subsection{The sharing way of accounting information}

According to the goal of "counting out one branch and sharing resources", taking counties as nodes, the accounting information platform is established in financial departments at all levels to comprehensively collect the accounting information of all units in the region. Through auditing, summarizing and analyzing, the accounting information is collected, stored and reported level by level, and the county, city, province and national accounting information platform is established to form a vertical connection, horizontal interaction, internal integration and national unification A new accounting information sharing service system. See Figure 1.

Through the establishment of accounting information platform, a national unified, horizontal interactive and vertical integrated accounting information sharing service system will be formed to realize "one platform, five level application" of accounting information. One platform refers to the national accounting information platform, which takes the county-level accounting information platform as the node, integrates the accounting information resources step by step, and establishes a comprehensive national unified accounting information service platform. Five level application refers to the use of accounting information platform to realize the sharing and application of accounting information by government departments at all levels of county, city, province and country and the public. Through vertical connection, the vertical accounting information sharing among government departments at all levels of country, province, city and county can be realized. Through horizontal interaction, the horizontal sharing of accounting information among government departments in the region can be realized, and the public can use the Internet Network access to the required accounting information services, accounting information to achieve the "number out of a door, resource sharing" goal.

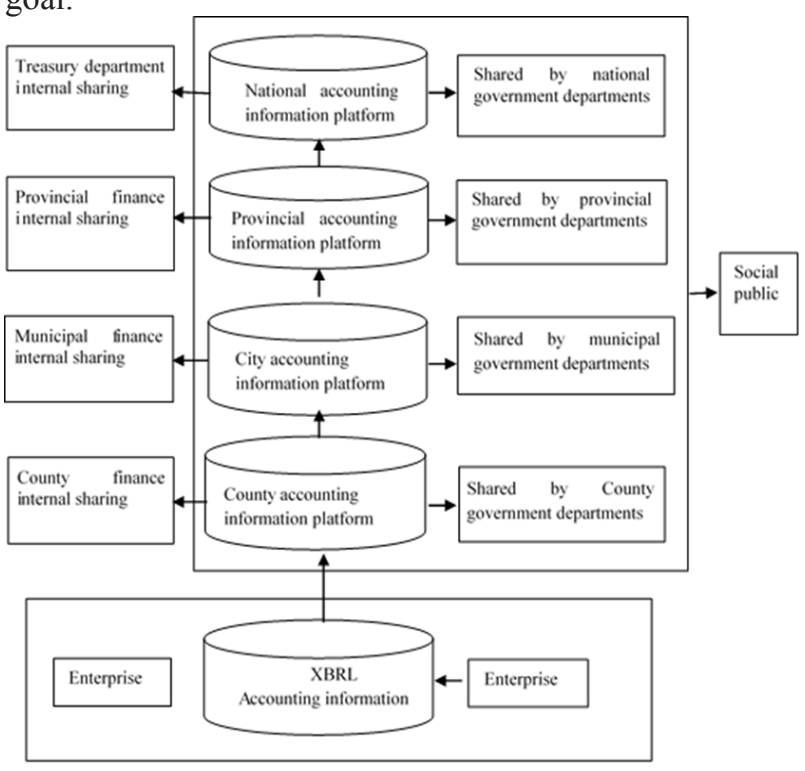

Fig. 1. The sharing way of accounting information

First, through vertical connection, the accounting information of financial departments can be collected and shared step by step. Taking the county as the node, comprehensively collect the accounting information of each unit in the region, and submit it to the superior financial department through audit, summary and analysis, so as to realize the level by level collection and vertical sharing of accounting information. Through vertical connection, the accounting information database is established in financial departments at all levels to lay the foundation for accounting information sharing, solve the problems of decentralized management and non sharing of accounting information, and ensure the 
authenticity, reliability and integrity of accounting information through data audit.

Second, through horizontal interaction, the accounting information of financial department and other relevant government departments can be interconnected. The accounting information required by the relevant government departments is provided by the financial department and obtained directly from the accounting information platform, so as to realize the regional accounting information "counting out one door and sharing resources", solve the problems of multi submission, different caliber, decentralized management and independent management of accounting information, realize the sharing of cross department supervision information, promote the organic combination of all kinds of supervision, and improve the macro-control system to enhance the coordination of macro-control.

Third, through business integration, the integration and integration of internal accounting information and related business of financial department can be realized. The accounting information required by various internal businesses of the financial department, including budget management, treasury centralized payment, financial supervision, etc., is provided by the accounting information platform to realize the integration and integration of accounting information and related businesses, promote the construction and integration of business system integration, solve the problems of internal businesses of the financial department being independent of each other, holding one share and serving one's own needs, and realize the goal of the Ministry of finance The internal accounting information of each department should be "counted and shared", so as to enhance the effectiveness and scientificity of macrocontrol decision-making and improve the level of financial governance.

Fourth, unify the whole country to meet the needs of the public and other accounting information users. Establish a national unified accounting information sharing standard system, such as standard specification, data structure and storage format, solve the problems of data standard and format that hinder the sharing of accounting information, and lay a foundation for the acquisition, exchange and sharing of accounting information. The higher the transparency of accounting information, the higher the degree of supervision and restraint on economic behavior, so as to improve the legitimacy and effectiveness of accounting information and give full play to the governance effect of accounting information $^{[3-4]}$. Through the establishment of accounting information platform, on the basis of government accounting information sharing, the public and other accounting information users can query accounting information through the Internet, meet the needs of the public and other accounting information users, strengthen social management and public service functions, and improve the governance effect of accounting information.

Fifth, it is open and transparent to facilitate the public and other information users to obtain accounting information. The public and other information users can obtain the corresponding accounting information through websites and other channels according to the requirements of the platform, and provide multi-level, diversified and personalized services. Through the accounting information platform, the relevant government departments can regularly release relevant information to the public, such as the quality inspection announcement of accounting information, so as to play the dual supervision role of the government and other information users.

\subsection{Service mode of accounting information sharing}

\subsubsection{Users of accounting information and their needs}

According to the characteristics of accounting information users, they can be divided into three categories: financial departments, government departments, the public and other stakeholders. Accounting information sharing should serve national governance and serve them at the same time. The financial department, responsible for the management of Finance and accounting, is the main user of accounting information. Relevant government departments, including market supervision and administration department, tax department, securities supervision department, statistics department and state-owned enterprise supervision department, use accounting information as the basis of macro management and control according to their respective functions. The public refers to organizations and personnel outside government departments. The public, including enterprise managers, employees, creditors, investors, customers, suppliers, trade associations and intermediaries, has the right to know about the operation of enterprises. Finance and other government departments are relatively concentrated, and the public is relatively scattered.

The content and form of accounting information demand are different with different goals of accounting information users. From the perspective of the demand content of accounting information users, there are both financial information and non-financial information, even including background information and forwardlooking information; from the perspective of information form, there are both quantitative information and qualitative information, both original information and summary information, both surface information and analysis information.

According to the different requirements of users, information is divided into interactive information, special information and public information.

Public information, including accounting statements and other basic information, as well as the public information released by various government departments, can be inquired by the public and other users of accounting information.

Special information refers to the relevant information used by government departments for macro-control and market supervision according to their respective 
management functions, such as tax information of tax departments, for internal use by relevant government departments.

Interactive information, the relevant information released by government departments for sharing by other government departments, such as the quality inspection of accounting information released by financial supervision, can be directly used by audit, securities and other relevant departments to promote the organic combination of supervision and improve the effectiveness of macro-control.

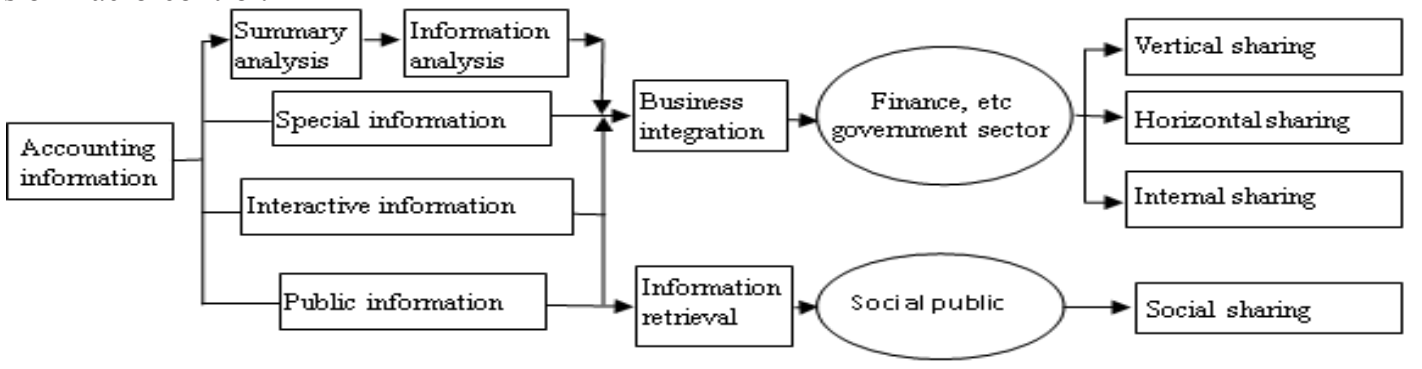

Fig. 2. Service mode of accounting information

Business integration service mode. Relevant business systems of Finance and other government departments are directly integrated with the accounting information platform to realize information interconnection and share accounting information through XBRL standard data interface to ensure the integrity, accuracy and timeliness of information sharing.

Information retrieval service mode. The public and other users of accounting information query accounting information through the Internet.

In order to give full play to the role of accounting information and meet the needs of different information users, accounting information sharing is divided into vertical sharing, horizontal sharing and social sharing, as shown in Figure 2.

Vertical sharing refers to the sharing of accounting information between higher government departments and lower government departments. It can be divided into bottom-up and top-down.

Horizontal sharing refers to the sharing of accounting information between government departments.

Social sharing, information users can easily obtain accounting information. We should realize the openness and transparency of accounting information, give full play to the role of accounting information, and improve the ability of national governance.

\section{Integration of accounting information resources}

\subsection{Problems of accounting information sharing}

Only by collecting and integrating accounting information can it be shared by users of accounting information. At present, the accounting information of Listed Companies in China has been publicly disclosed on the website designated by the stock exchange, and information users can obtain it through retrieval and

\subsubsection{Service mode of accounting information sharing}

Through business integration service mode, it provides special accounting information for government departments; through retrieval mode, it provides public accounting information for the public, as shown in Figure 2. other means. However, the accounting information platform is quite different from the website of the stock exchange in terms of disclosure content, scope and sharing mechanism. In terms of the scope of disclosure, the website of the stock exchange only discloses the accounting information of listed companies. At present, there are less than 3500 listed companies in China, so it is relatively easy to integrate resources. The accounting information platform includes the accounting information of all enterprises and administrative institutions, and there are more than 377000 Industrial Enterprises above Designated Size in China, distributed in 2800 provinces across the country Many counties and districts ${ }^{[5]}$, with wide distribution and huge amount of information, face many technical problems in resource integration. In terms of disclosure content, the website of the stock exchange mainly discloses the basic accounting information, corporate governance characteristics, stock market and other related information of listed companies; besides the basic accounting information, the accounting information platform also includes the relevant business information required by the management functions of relevant government departments. In terms of sharing mechanism, the website of the stock exchange is mainly for investors and other public, providing services through information retrieval; in addition to providing services for the public, the accounting information platform also needs to be interconnected and shared with government departments at all levels. Therefore, the integration of accounting information resources of listed companies can not meet the functional requirements of accounting information sharing.

\subsection{The basic thinking of accounting information resources integration}

The integration of accounting information resources is based on the accounting information of enterprises and administrative institutions to realize the process of accounting information collection, verification, 
standardization, transmission and storage, and lay the foundation for accounting information sharing. Cloud computing technology integrates the hardware, software and data scattered in different geographical locations through the network to provide unified management and scheduling for users. This service mode provides an effective way to integrate accounting information resources and realize accounting information sharing. The basic ideas are as follows: distributed storage and centralized management; unified scheduling and resource sharing; centralized control to ensure security; dynamic expansion to reduce investment.

\subsection{Resource integration of accounting information}

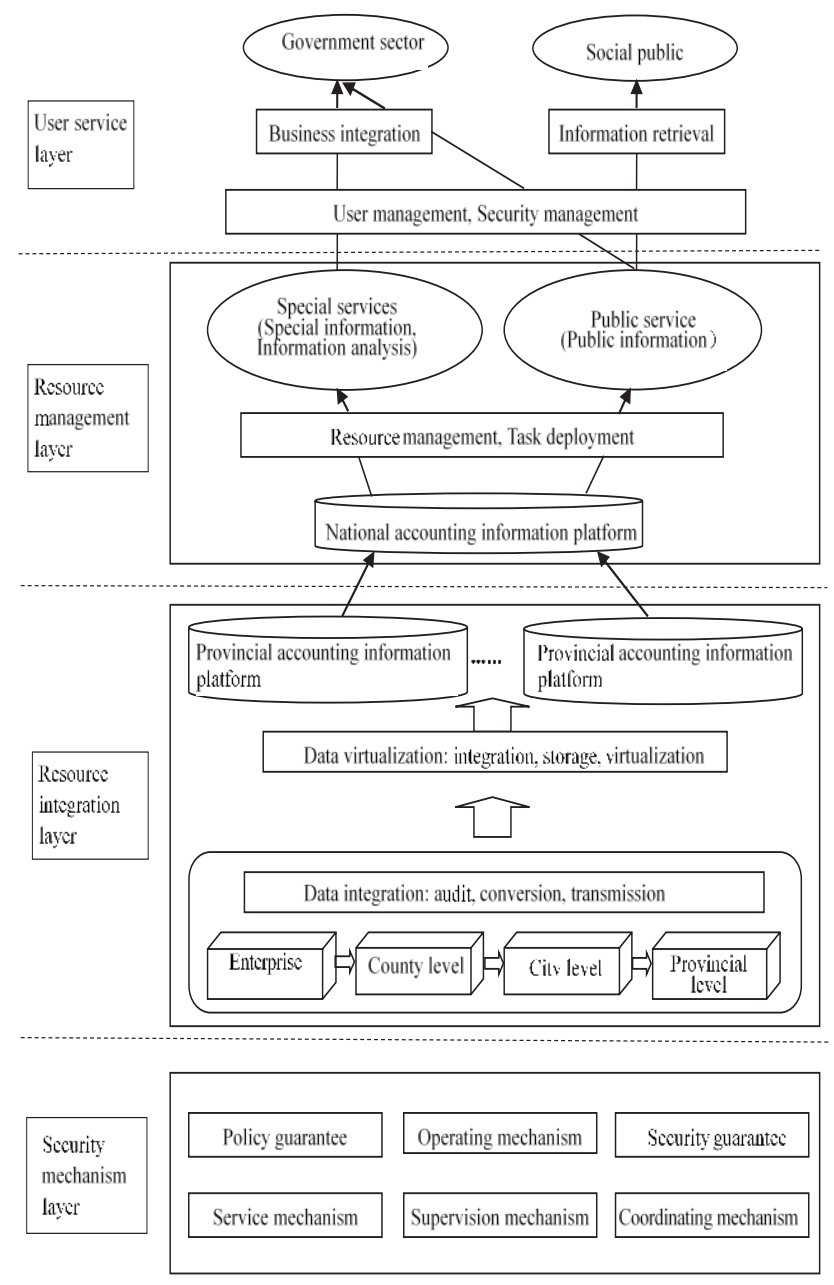

Fig. 3. The integration method of accounting information resources

\subsubsection{Collection of accounting information}

The collection of original details by accounting information platform is conducive to guarantee the authenticity of information and improve the quality of accounting information. At present, the accounting information platform can not reasonably guarantee the authenticity of such a large number of original
According to the goal of "counting out one door and sharing resources", accounting information resources integration takes county as the node and province as the foundation, establishes accounting information platform at all levels of financial departments, comprehensively collects accounting information of all units in the region, collects, stores and reports level by level through audit, summary and analysis, establishes County, city, province and national accounting information platform, and forms a vertical connection Accounting information sharing service system with horizontal interaction, internal integration and national unification. Through "special service", realize the interconnection and information sharing among the national, provincial, municipal and county governments and their relevant departments, and provide information inquiry and other services to the public through "public service". See Figure 3. 
inspection and confirmation, to ensure the authenticity, legitimacy, rationality and effectiveness of accounting information.

\subsubsection{Resource integration}

Integrate accounting information resources. The accounting information of enterprises is reported to the county-level financial departments. The county-level financial departments are integrated into the virtual environment to form the municipal accounting information platform. The municipal financial departments are integrated into the virtual environment to form the provincial accounting information platform. The provincial accounting information platform is integrated into the virtual environment to form the "national accounting information platform".

\subsubsection{Resource management}

Resource management and task deployment. Resource management is responsible for the allocation of resources to public service system and special service system to ensure information security. Task allocation is to allocate resources reasonably and serve users efficiently.

Summary and analysis of accounting information. According to the needs of the users of accounting information, summarize and analyze the accounting information to form the summary analysis results. There should be not only the summary information suitable for professionals, but also the summary information needed by ordinary information users.

\subsubsection{User services}

Provide services for users, do a good job in user management and security management. Deploy accounting information appropriately. Provide corresponding services according to the sharing mode of accounting information users. Through access control ensure the security of information services.

Government functional departments. By using the information sharing method based on business integration, the special information of the special service system and the public information of the public service system are called; the relevant business information is transmitted to the special service system through the accounting information platform for sharing by other departments, so as to realize the interconnection of regulatory information, and release the regulatory and other public information to the public service system for public inquiry。

The public. The public include other departments, institutions and general investors. Through the comprehensive information module in the accounting information platform, we can query the public information in the public service system.

\subsubsection{Safeguard mechanism}

Guarantee mechanism includes policy guarantee mechanism, operation mechanism, security guarantee, service mechanism, supervision mechanism, coordination mechanism, etc. Ensure the security of accounting information storage and transmission, and avoid errors or tampering.

\section{Implementation and application of accounting information sharing}

\subsection{The construction subject of accounting information platform}

There are three views on who should build the accounting information platform: first, the financial department should be responsible for the construction; second, the competent department of the industry should be responsible for the construction; third, the accounting information market should be established.

This paper suggests that the construction of accounting information platform should be led by the financial department. The financial department is familiar with the financial situation and has its unique advantages in the collection, transmission and utilization of accounting information. The position of the financial sector in the market enables it to maintain a neutral attitude in economic activities and coordinate and mobilize the interests of all parties concerned. The construction of accounting information platform is dominated by the financial department, which can ensure the authenticity of accounting information and effectively supervise and manage accounting information. At the same time, the market can also participate in the construction of accounting information platform, and make use of its advantages to play a supporting role.

\subsection{Construction strategy of accounting information platform}

First, overall planning, step-by-step implementation, and gradually expand the scope and function of accounting information sharing. Second, bring accounting information sharing into the financial information construction system. Third, formulate corresponding policies and regulations to ensure the construction and operation of accounting information platform. Fourth, develop corresponding software. Fifth, coordinate the relationship between accounting information platform and enterprises, and pay attention to ensuring information security. Sixth, strengthen accounting construction.

\subsection{Operation mode of accounting information platform}

The possible operation modes of accounting information platform include government operation mode, market 
operation mode and mixed operation mode of government and market.

This paper suggests the government led mixed operation mode. The simple government operation mode makes the financial department overburdened, while the market-oriented operation mode makes the function of accounting information platform unable to give full play. It is suggested that the Ministry of finance should lead, the financial departments at all levels should operate the accounting information platform at all levels, and other government departments should cooperate to give full play to the leading and supervising role of the government. At the same time, improve and make use of the accounting information market to play its advantages.

\subsection{Application of accounting information platform}

Accounting information sharing provides an effective way for government departments and the public to obtain accounting information. We should make full use of accounting information. First, deeply excavate the value of accounting information resources. Mainly includes: accounting information fraud identification, macroeconomic benefit analysis, key enterprise economic benefit analysis. Second, innovate the use of accounting information resources. Through business integration, realize business system integration. Through process reengineering, improve the efficiency of accounting information utilization.

\section{Conclusion}

Accounting information sharing plays an important role in giving full play to the resource allocation effect of accounting information and promoting the modernization of national governance. From the perspective of national governance, this paper discusses the accounting information sharing mechanism in order to achieve the goal of "counting one door and sharing resources". This paper specifically introduces the significance of accounting information sharing to national governance, the realization mechanism of accounting information sharing, the integration of accounting information resources, and the implementation and application of accounting information sharing.

\section{Acknowledgement}

This study is supported by the National Social Science Fund Project "Research on Accounting Information Sharing Mechanism from the Perspective of National Governance", No: 15BGL057.

\section{References}

1. Treasury department. (2016), Notice of the Ministry of Finance on printing and distributing "the outline of the 13th five year plan for accounting reform and development" (Cai Kuai [2016] No.19) . Finance and accounting, (22): 6-11

2. Qiu H. P. (2015), Making the market play a decisive role in resource allocation and giving better play to the role of the government -- the new development of socialist economics with Chinese characteristics. Academic journal, (09): 47-60

3. Qi H. D, Huang Y. Q. (2009), Information disclosure of non listed state-owned enterprises in China: Current situation analysis and system design [J]. Managing the world, (2): 174-175

4. Xie Z. H. (2014), On the economic effect of accounting [J]. Accounting Research, (6): 8-16

5. National Bureau of Statistics. (2021), China Statistical Yearbook 2020[EB/OL] 